Council members, awards of the Dalton Medal and special lectures, Sir William Slater's Joule Memorial Lecture, "The State as the Patron of Science". Other papers in the Memoirs include those by K. F. Bowden on progress in oceanography; N. L. Hanson on "The Architect's Dilemma"; G. Polanyi on "North Sea Gas-What will it Mean ?", F. Oldfield and D. C. Statham on "Stratigraphy and Pollen Analysis on Cockerham and Pilling Mosses, North Lancashire"; R. H. Kantorowich on "Choice and Chance--Prospects for the North-West"; Brian Rodgers on "Making Social Policy"; and an autobiographical sketch of J. B. Dancer, with a foreword by W. Browning.

\section{National Art Gallery and Dominion Museum, New Zealand}

THE year 1965 marks the centennial year of the Dominion Museum and is being celebrated by evening functions, special exhibitions and the publication of a history of the Museum. In addition to various curatorial activities, the extra-mural influence of tho institution is particularly impressive and includes circulation of works of art and museum specimens, public lectures, scientific excursions and advice on conservation. Exhibition effort has been concentrated mainly in the Maori Hall, new cases of foreign aviary birds, early silver, and the completion of a reconstruction of an Egyptian tomb (a lifesized $\mathrm{X}$-ray negative of the mummy was added to this exhibit). The report for the year ended March 31, 1965, also records the opening of the Hall of Memories in 1964 and comments on the beauty and artistry of the interior and the manner in which the symbolic message is conveyed (New Zealand. Report of the Board of Trustees of the National Art Gallery and Dominion Museum for the year ended 31 March, 1965. Pp. 28. (H.21.) Wellington: Government Printer, 1965. 1s. 6d.).

\section{French Oceanography}

The September 1965 issue of Le Progrès Scientifique (No. 88) is devoted to a survey of the situation and perspectives of French oceanography, with, for comparison, an estimate of expenditure on oceanography in Great Britain and in the United States programme for 1966. Some 596 scientists and engineers are estimated to have been engaged on oceanographic research in France in 1964, equivalent to 450 full-time workers; the corresponding expenditure is estimated at 90-100 million francs. There is also a brief account of three recent French contributions to the advance of oceanographic technique in the Bouée laboratory, the submarine seismograph, and the Télénaute.

\section{Chemical Analyses of Rocks and Minerals}

THE latest of a recont succession of regional compilations of chemical analyses of rocks and minerals, prepared to facilitate the more ready use of data in the files of Government departments, emanates from the Geological Survey of Canada and is the first part of a project designed to bring together all available Canadian geochemical information (Canada: Department of Mines and Technical Surveys. Geological Survey of Canada. Bulletin 115: Chemical Analyses of Canadian Rocks, Minerals, and Ores. By J. A. Maxwell and others. Pp. 476. Ottawa: Queen's Printer, 1965. 6.50 dollars). It comprises analyses, with potrographical and topographical annotations, made by the Survey from the time of its foundation in 1846 up to the end of 1955 . This follows closely on a similar monograph based on sixty years of records of the Geological Survey of Malaya (Geological Survey of Malaya Professional Paper E-64: Chemical Analyses of Malayan Rocks, Commercial Ures and Mineral Concentrates. Compiled by J. B. Alexander and others. Pp. 295. Ipoh: Malaysian Ministry of Lands and Mines, 1964. 10.00 Malayan dollars). In the U.S.S.R., an important regionally based collection of some 2,000 full (but not annotated) chemical analyses of rocks and rock-forming minerals, mostly executed in recent years, has appeared under the aegis of the Institute for OreDeposit Geology, Petrography, Mineralogy and Geochemistry (Khimicheskie analizy izverzhennykh gornykh porod $i$ porodoobrazuyushchikh mineralov. Compiled by V. F. Morkovkina. Pp. 250. Nauka, Moscow, 1964. 3r. 66k). It carries useful caleulations of the average composition of the more important rock-types in the several regions of the U.S.S.R. A fourth recent work of this kind is a compilation by Miss Germaino A. Joplin of the analyses in Australian literature (Chemical Analyses of Australian Rocks. Part 1: Igneous and Metamorphic. Bureau of Mineral Resources, Geology and Geophysics. Bulletin, 65. Pp. 446. 1963). Part 2 of the Australian monograph, on sedimentary rocks, is in preparation. These several works bring together data from a wide range of sources and they will save petrologists much tedious searching of the literature.

\section{Chiswick-Langley Section of the M.4 Motorway}

THE Chiswick-Langley section of the M.4 motorway opened by Mr. T. Fraser, the Minister of Transport, on March 24, 1965 , is 12.5 miles long, and contains the longest stretch of elevated road in Europe; incidentally, it also incorporates a much-needed link road to London Airport. Some interesting details of the design and construction of this highway, with its viaducts, overbridges, underbridges and footbridges, some of which are illustrated, are contained in an article, "Chiswick-Langley Section of the M.4" (Concrete Quarterly, No. 65; AprilJune, 1965. Cement and Concrete Association, London). For about the first 2 miles from the Chiswick end, this motorway is a viaduct with two twin-lane carriageways. The first mile or so is constructed with pre-cast, prestressed concrete deck beams carried on T-shaped piers; this follows the line of the Great West Road. The remainder of the viaduct swings away from the Great West Road and is of steel and concrete construction. Thero are thirty-one bridges between Chiswick and Langley, including the link road to London Airport; these owe their lightness of form and speed of construction to the use of pre-cast concrete units and pre-stressing techniques. Twelve bridges carry roads over this new section of the M.4; sixteen carry the motorway itself over roads, railways, canals and rivers; three footbridges are available for pedestrians, and sixteen pedestrian subways have been constructed at various points along it. At the end of the elevated section, where it desconds to ground-level, the carriageways widen to accommodate three $12-\mathrm{ft}$. lanes; outside these carriageways are constructed hard shoulders, $10 \mathrm{ft}$. wide, bounded by grass verges of similar width. The length of approximately 7 miles between Boston Manor and London Airport is in concrete; between the Airport and Langley interchanges there are approximately 4 miles of flexible construction on various bases; this section was purposely laid for practical specification trials by the Road Research Laboratory. It is stated that the concrete road slab is $38 \mathrm{ft}$. wide, 11 in. thick, with welded steel mesh reinforcement $3 \mathrm{in}$. below the top surface. The consolidated granular sub-base is between 7 in. and 12 in. thick. Expansion joints are provided every $240 \mathrm{ft}$. and contraction joints at 80 -ft. centres. The illustrations in this article, including one of the olevated section of the motorway with slip roads at the Brentford interchange, and one of an elegant pre-stressed footbridgo with spiral ramp at the Langley interchange, are particularly good.

\section{Shrinking Aggregates a Cause of Failure in Concrete}

There exists an extensive literature on research into failure of concrete ascribed to instability of aggregates involved, both physical and mineralogical. Aggregates known to exhibit excessive dimensional change on drying out and ageing of concrete would normally be inad- 